\title{
The relationship between country risk and company performance in Southeast Asia
}

\author{
Meyliana \\ Hendra Bunyamin \\ Lidya Agustina \\ Maranatha Christian University, Indonesia
}

Keywords

Country risk, company performance, ROE, machine learning algorithms

\begin{abstract}
Managing risk is important. Organizations are starting to see the value of, or asking for strategic solutions to managing the risk. Risk refers to a deviation from what the organization plans or expects. Risk has an upside (opportunity), as well as a downside, the potential negative impact to an asset. This type of risk (loss) can prevent companies from achieving strategic goals. Organizations can turn risks into opportunities through effective risk management.

For public companies which have subsidiaries in many countries, one of the risks should be managed is country risk. Country risk is defined as the risk a foreign government will default on its bonds or other financial commitments. Country risk also refers to the broader notion of degrees to which political and economic unrest affects the securities of issuers that do businesses in a particular country.

In this research, we analyze the effect of country risk on company performance. Moreover, we employ linear regression to model the effect and the result shows country risk has a significant negative influence on Return on Equity (ROE). We also build nine models to predict country risk ratings based on country risk reports by utilizing machine learning algorithms. Furthermore, decision tree algorithm has the highest accuracy $31.25 \%$ on our dataset. Finally, our results show that, firstly, international companies who have overseas subsidiaries can benefit from using country risk as a tool to measure returns. Secondly, decision tree algorithm should be utilized to help decision makers determine country risks based on country reports; however, the effect of time-series data set into the machine learning algorithms still needs more investigations.
\end{abstract}

Corresponding author: Meyliana

Email addresses for corresponding author: meyliana_oey@yahoo.com

First submission received: $21^{\text {st }}$ August 2017

Revised submission received: $12^{\text {th }}$ October 2017

Accepted: 29th January 2018

\section{Introduction}

World Bank press release on $11^{\text {th }}$ April 2016 stated growth in Developing East Asia and Pacific has remained resilient and has been expected to ease only modestly between year 2016 and 2018 according to a new World Bank report. This outlook is subject to elevated risks; consequently, countries should continue to prioritize monetary and fiscal policies in order to reduce vulnerabilities and strengthen credibility, as also deepen structural reforms.

Various factors affect a risk of investing in a country. The risk dealt when investing in a country is termed country risk. Country risk is defined as a set of risks associated with investments in a foreign country ${ }^{1}$. Country risk consists of political risks, exchange rate risks, economic risks, and risks of foreign exchange setting policy in a country. Moreover, country risk in one country differs from the one in other countries. In general, the higher risk some countries have, the fewer foreign investments they have.

Country risk is one of the important points for assessing Organization Risk Management (ORM) and Enterprise Risk Management (ERM), specifically for organizations that have branches and/or subsidiaries in other countries. Country risk in one country extremely depends on various occurring factors and the government policy in dealing with problems faced by the state. Considering the great influence country

$1 \quad$ www.investopedia.com 
risk ratings to final decisions taken by countries, multinational companies attempt to calculate their country risks as part of ERM, either through ratings by outside agencies or self-rating.

Country risk ratings have been largely computed by agencies around the world, one example is the one in China where the country's risk rating was first performed in 1988, and currently there are more than fifty agencies listed carrying out a country risk rating (Mihaela and Alina, 2011). Country risk ratings are very useful to be used as a consideration and analysis of project decisions of multinational companies where the lower the country risk rating of a particular country means the higher the risk that will be faced by the company in accepting projects located in the location of the country.

A statement that applies to investors who play in the capital market is "High Risk, High Return" i.e. the higher the risk faced will be offset by high returns as a form of compensation due to high risk. This statement is in line with the research foundation conducted by Erb et al. (1996) who mentions that the higher country risk should be linked to higher expected return.

The purpose of this study has twofold. Firstly, it strives to test whether the "High Risk, High Return" statement will be repeated on data analysis testing the relationship between country risk and profitability in multinational companies in Southeast Asia. Moreover, the study attempts to build classification models that predict country risk ratings based on qualitative data.

The data used for examining country risk ratings in order of relationship with corporate profitability comes from sovereign credit ratings countries issued by Moody's. Damodaran (2017) calculate percentages of country risk based on the sovereign credit ratings. In addition, profitability data from multinational companies in Southeast Asia region obtained from the financial statements of multinational companies that have several branches or subsidiaries in the region of Southeast Asia also supports our analysis about the relationship. The measure of profitability is calculated in Return on Investment (ROI) and Return on Equity (ROE). Whereas data for building country risk ranking model is taken in the form of qualitative country report data in 2016 issued by Euler Hermes ${ }^{2}$. The country risk rating of Euler Hermes is divided into 2 parts: medium-term rating (Country Grade) and short-term rating (Country Risk Level). The former is measured by economic imbalances, quality of the business climate, and political influence of the country. Specifically, political influence of the country is divided into 6 levels ranging from AA that indicates the lowest risk level until rank D that signifies the highest level of risk. The latter portrays country's economic outcome over a period of 6-12 months; country risk level is measured through financial flows and seasonal risk. Particularly, seasonal risk is divided into 4 levels from 1 (lowest risk level) to 4 (highest risk level).

This study also explores the application of machine learning algorithms on country risk rating reports; specifically, we try to make models and make predictions of country risk rating. The machine learning algorithms that we will use to predict country risk ratings are as follows: Nearest Neighbors, Linear Support Vector Machines, Radial Bases Functions Support Vector Machines, Gaussian Process, Decision Tree, Random Forest, Neural Net, Ada Boost, and Naive Bayes.

This study explores 2 goals, such as test the relationship between country risk ratings with the profitability of firms that are represented by ROI and ROE and establish models for predicting country risk ranking using machine learning algorithms.

\section{Study of Literature}

\subsection{Country Risk and Company Performance}

Country Risk

Enterprise Risk Management (ERM) is a process that is affected by an entity's board of directors, management and other personnel, and is applied as a strategy setting across the enterprise; specifically it is designed to identify potential events that may affect the entity and to manage risks to be within its risk appetite, and to provide reasonable assurance regarding the achievement of entity objectives (COSO, 2004). ERM is designed as a system that can help management overcome the problem of uncertainty that poses a risk to the company. Moreover, ERM controls the risks that are developing in an integrated and holistic way. Failing to prevent, assess, and manage risks may cause harms to stakeholders and

2 www.eulerhermes.com/economic-research/country-risks/Pages/country-reports-risk-map.aspx\#countryreports 
shareholders; consequently, the company has to anticipate risks in creative ways (Shenkir and Walker, 2007). In addition, ERM can help companies achieve ERM objectives and implementation directly with corporate strategy (Sanjaya and Linawati, 2015).

ERM programs have more benefits by providing adequate information about the company's risks. Public tends to have difficulty in assessing the strength and financial risks of companies; therefore, ERM allows companies to provide financial and nonfinancial information to public about the company's risk profile and also serves as a signal of commitment to managing risks (Hoyt \& Liebenberg, 2011).

The risks faced by companies, especially multinational corporations, are growing; therefore, companies need to consider the risks of the country not only in the countries where the companies open their businesses but also in the countries that will be the export destinations and/or where the companies' subsidiaries will be established. Some risk characteristics of a country can greatly affect companies' performance.

Before deciding to invest in a country, a multinational company needs to consider all the risks that may arise, including risks that may arise in the country where one will invest. Country risk model is a model designed to measure and compare risks of investing in a country and can be compared with the ones of other countries, so investors can see the risk of investing in a country whether in large or small amounts. Country risk can be indicated by both qualitative and quantitative factors. Both factors based on The Economist Group (2016) used to collect quantitative and qualitative data are as follows:

1. Sovereign risk measures the risk of a build-up in arrears of principal and/or interest on foreign and/or local-currency debt that is the direct obligation of the sovereign or guaranteed by the sovereign.

2. Currency risk measures the risk of maxi-devaluation against the reference currency (usually the US dollar, sometimes the euro) over the next 12-month period.

3. Banking sector risk gauges the risk of a systemic crisis whereby bank(s) holding $10 \%$ or more of total bank assets become insolvent and unable to discharge their obligations to depositors and/or creditors.

4. Political risk evaluates a range of political factors relating to political stability and effectiveness that could affect a country's ability and/or commitment to service its debt obligations and/or cause turbulence in the foreign exchange market.

5. Economic structure risk encompasses a series of macroeconomic variables of a structural rather than a cyclical nature.

6. Overall country risk is derived by taking a simple average of the scores for sovereign risk, currency risk, and banking sector risk.

\section{Company performance}

Company performance, often called the operation performance, can be assessed through financial performance that is the fundamental aspects of a company. In this study the company's performance is measured by using profitability analysis that reflects the company's ability to generate profits.

According to Husnan (2001), profitability is the ability of a company to get a profit within a certain period. Michelle and Megawati (2005) define profitability as a company's ability to generate profits that will be the basis of dividend distributed in a company. Profitability of a company affects the policy of investors on the investment. The ability of a company to generate profits will be able to attract investors to invest funds in order to expand its business, whereas a low level of profitability will cause investors to withdraw their funds. As for a company itself profitability can be used as an evaluation of the effectiveness of the management of an enterprise (Brigham and Gapenski, 1993).

The company's ability to generate profits measured through profitability ratios is a measure of return that investors will gain in the future; therefore, a company with the ability to generate a high profitability ratio is a sign for investors to immediately invest in that company. In this study assessment of company performance is based on profitability analysis (Handayani, et al. (2011)) as follows:

1. Return on Investment (ROI)

According Sutrisno (2009) Return on Investment (ROI) is the ability which is used to cover the investment that has been made. Earnings used to measure the ratio is net profit after tax. Return on Investment (ROI) is measured by comparing the earnings with total assets. 
2. Return on Equity (ROE)

According Martono and Harjito (2006) Return on Equity (ROE) is used to measure profits that are the rights of the owners.

$$
\mathrm{ROE}=\frac{\text { NetProfit }}{\text { AverageEquity }}
$$

\subsection{Country Risk Rating Model with Machine Learning Algorithms}

The more intensity of international transactions involving assets and loans between countries, the higher the risks faced (Mihaela and Alina, 2016). Consequently, we draw a conclusion that the ranking to assess the risk in a country is very important given the current global economic conditions. Country risk ratings have been widely developed; moreover, this is supported by the evidence that there are numbers of existence of various websites that provide information on country risk ratings.

Various ranking agencies in the world try to generate an assessment of the latest opportunities and provide business opportunities in new markets; therefore, it is useful to provide useful information for investors in making investment decisions. Country risk rating is based on data that can be used as a reference based on Euler Hermes, such as the imbalance of the economy, the quality of the business climate, and the political influence of the country. Assessments of country risk ratings will be generated based on the data; moreover, this assessment differs from country to country and country risk rating mainly becomes the basis of investors in making investment decisions. We also intend to model country risk ranking using machine learning algorithms and analyze how much the model can predict the country risk rating compared to the country risk rating issued by Euler Hermes.

Text Mining

The definition of Text Mining (Hearst, 2003) is "the discovery by computer of new, previously unknown, information by automatically extracting information from different written resources". The computer automatically extracts information from various written documents and then finds information that has not previously been found.

Text Mining is described as a process to extract interesting and interesting information from unstructured text data (Hotho et al., 2005). They further explained that actual text mining is an interdisciplinary method of information retrieval science, machine learning, statistics, computational linguistics, and data mining. Text mining is also defined as "the discovery and extraction of interesting, non-trivial knowledge from free or unstructured text" (Kao and Poteet, 2007). Kao \& Poteet further describes that text mining includes all of the information retrieval (document or web site retrieval) into text classification, text clustering and also entity, relation, and event extraction. Text mining is similar to data mining; the fundamental difference is in the inputs. Data mining processes inputs, such as structured data from a database or XML file while inputs to text mining are unstructured data or semi structured data sets (such as email, full-text documents and HTML files) (Fan et al., 2006).

Typically, from existing document collections text mining applications retrieve certain documents and preprocess them by checking document formats and character sets. Furthermore, the documents are incorporated into text analysis process; text analysis techniques can be repeated until the information to be searched is found. Three main techniques of text analysis are information extraction, clustering, classification, and summarization; however, the techniques that can be used depends on the purpose of the organization that uses text mining. Information that has been found can be stored in a management information system and users can gain knowledge from that information.

\section{Classification Models}

One of the objectives of this research is to build models based on Country Risk Report issued by Euler Hermes. Given a collection of Country Risk Reports, models are used to predict country risk of a country. To achieve this goal, machine learning models will be used to model the relationship between text within Country Overview and Country Risk Rating (Barber, 2012).

\section{Research Method}

\subsection{Sample Selection}

The population in this study are all multinational companies listing on the Southeast Asia Regional Stock Exchange. We employ purposive sampling as the sampling technique with the following sampling criteria: 
1. The company is a multinational company that has several subsidiary branches and listed on the stock exchange from 2010 until now in one of Southeast Asian Region Countries.

2. The company issues Annual Financial Statements from 2010 - 2015 in a row.

3. The company is never delisted between $2010-2015$.

After listing the population of multinational companies listed on the Southeast Asia Stock Exchange, most of the multinational companies are banking companies; the reasons are that these companies use the same name as the parent, whereas other multinational companies are mostly renamed and not the same as the parent's company name; therefore, it is difficult for researchers to find the required data. The banking companies which become objects in this research are as follows:

\begin{tabular}{|c|l|l|}
\hline No. & \multicolumn{1}{|c|}{ Company Name } & \multicolumn{1}{c|}{ Country Branches } \\
\hline \hline 1 & Commonwealth & Indonesia \\
\hline 2 & HSBC Bank & China, Hongkong, Indonesia, Japan, Korea, Malaysia, Thailand, Vietnam \\
\hline 3 & Citibank & Hongkong, Indonesia, Japan, Malaysia, Taiwan, Thailand \\
\hline 4 & Royal Bank of Scotland & Hongkong, Malaysia \\
\hline 5 & Hang Seng Bank & China, Hongkong, Indonesia, Korea \\
\hline 6 & OCBC NISP & China, Singapore, Indonesia, Malaysia \\
\hline 7 & Hana Bank & China, Hongkong, Indonesia \\
\hline 8 & Standard Chartered & China, Hongkong, Indonesia, Malaysia, Taiwan, Thailand \\
\hline 9 & ANZ & China, Indonesia \\
\hline
\end{tabular}

\subsection{Steps for Country Risk Analysis and Company Performance Relationships}

Country risk rating data is obtained from Damodaran calculation (2017) ${ }^{3}$ which translates sovereign risk rating by Moody's into country risk premium percentage. Additionally, the company performance data is projected into ROI and ROE taken from the financial statements of 9 multinational banking companies for 6 consecutive years (in 2010 - 2015).

Based on country risk premium percentage data as X, ROI calculation (Y1) and ROE calculation (Y2) are analyzed by using simple linear regression to find correlation and influence country risk to company performance.

\subsection{Research Method Steps in Text Mining}

One of the objectives of this research is to model the relationship between text corpus and country risk ratings. Text corpus is taken from Economic Overview and the ratings are for countries in Southeast Asia.

\section{Results}

The influence of Country Risk on ROI and ROE

By utilizing simple linear regression with Ordinary Least Square criteria, the following results are obtained:

ANOVA X1Y1

\begin{tabular}{lrrrrr}
\hline & $d f$ & \multicolumn{1}{c}{ SS } & \multicolumn{1}{c}{ MS } & $F$ & Significance $F$ \\
\hline Regression & 1 & 2207.97 & 2207.97 & 0.631254 & 0.427776016 \\
\hline Residual & 214 & 748519.3 & 3497.754 & & \\
\hline Total & 215 & 750727.3 & & & \\
\hline
\end{tabular}

ANOVA X1Y2

\begin{tabular}{cccccc}
\hline & $d f$ & $S S$ & $M S$ & $F$ & Significance $F$ \\
\hline Regression & 1 & 17389721 & 17389721 & 6.038372 & 0.014793588 \\
\hline Residual & 214 & $6.16 \mathrm{E}+08$ & 2879869 & & \\
\hline Total & 215 & $6.34 \mathrm{E}+08$ & & & \\
\hline
\end{tabular}

3 http://pages.stern.nyu.edu/ adamodar/New_Home_Page/datafile/ctryprem.html 
VALUE OF REGRESSION COEFFICIENT X1 Y2

\begin{tabular}{ccccccccc}
\hline & Coefficients & $\begin{array}{c}\text { Standard } \\
\text { Error }\end{array}$ & t Stat & P-value & Lower 95\% & $\begin{array}{c}\text { Upper } \\
95 \%\end{array}$ & $\begin{array}{c}\text { Lower } \\
95.0 \%\end{array}$ & $\begin{array}{c}\text { Upper } \\
95.0 \%\end{array}$ \\
\hline Intercept & 595.9454331 & 182.3203 & 3.268672 & 0.001259 & 236.5717692 & 955.3191 & 236.5718 & 955.3191 \\
\hline X Variable 1 & -18532.68626 & 7541.86 & -2.45731 & 0.014794 & -33398.5311 & -3666.84 & -33398.5 & -3666.84 \\
\hline
\end{tabular}

\begin{tabular}{cc}
\multicolumn{2}{c}{ R VALUE X1 Y2 } \\
\hline \multicolumn{2}{c}{ Regression Statistics } \\
\hline Multiple R & 0.165657348 \\
\hline R Square & 0.027442357 \\
\hline Adjusted R Square & 0.022897695 \\
\hline Standard Error & 1697.017763 \\
\hline Observations & 216 \\
\hline
\end{tabular}

A simple linear regression test was conducted twice; the first is to test the relationship between country risk premium and ROI. However, based on the analysis results ANOVA X1 Y1 table and the significance value $\mathrm{F} 0.4278$ is greater than the value of $\mathrm{Za} 0.05$. Therefore, we conclude that country risk premium variable has no effect on ROI variable.

In contrast to the results of the $\mathrm{X} 1 \mathrm{Y} 1$ test, utilizing simple linear regression analysis results that the significance value F 0.015 (rounded) is below the $\mathrm{Z}$ value of 0.05 (explained in ANOVA X1 Y2 table), which means that $\mathrm{H}_{0}$ is rejected and $\mathrm{H}_{1}$ is accepted. While the table of regression coefficient value obtained by regression equation shows that: $\mathrm{Y}=595.95$ - 18532.69X; moreover, table value $\mathrm{R}$ shows that the value of adjusted $R$ square 0.02289 . The overall information concludes that country risk premium variable significantly negatively affects the ROE, and the magnitude of influence is only $2.3 \%$.

\section{Text Mining Application to Predict Country Risk}

Euler Hermes country report is an in-depth research report depicting the economic profile of a country $^{4}$. A total of 120 country reports on the 4th quartile (Q4) of 2016 are used as data sets to predict country risk ratings.

A country report has the following structure:

- General Information

- GDP (Gross Domestic Product in US dollars)

- Population of the country

- Form of state

- Head of government

- Next elections

- Country Rating

- Strengths (The power factors that improve the investment climate)

- Weaknesses (The power factors that degrade the investment climate)

- Economic Overview (The state of the economy as a whole)

Country rating prediction problem is cast as a classification problem. The data set model is built using texts in Strengths, Weaknesses, and Economic Overview sections of a country risk report. Here are the steps to build a classification model:

1. Text is chopped up into pieces (tokens, words).

$4 \quad$ http://www.eulerhermes.com/economic-research/country-risks/Pages/country-reports-riskmap.aspx\#country-reports 
2. Each word that is a stop word is removed.

3. Words that are not stop words are processed by a stemmer and the process changes each word into its word stem. Example: 'abandoned' becomes 'abandon' and 'absorption' becomes 'absorpt'.

4. Total number of words is 3449; subsequently, a global dictionary records word frequencies from all country reports. The global dictionary consists of pairs of each word and its frequency. Basically, there is only one global dictionary.

5. Besides a global dictionary, a local dictionary records each word and its frequency from each country report. Since there are 120 country reports, the number of local dictionaries is 120 .

6. Terms-documents matrix is created by utilizing information from the previous dictionaries. Tokensdocuments matrix has a size of 120 documents $\times 3449$ tokens (words). An element $(i, j)$ of the matrix is a frequency of word $j$ in document.

7. Moreover, $40 \%$ of 120 documents that is 48 documents are separated randomly from country risk report collection as a test set.

8. The rest that is $60 \%$ from 120 documents (72 documents) is train set.

9. Machine learning algorithms used in this research are nearest neighbors, linear Support Vector Machines (SVM), Radial Basis Function (RBF) SVM, Gaussian Process, Decision Tree, Random Forest, Neural Net, AdaBoost, and Naive Bayes. Total number of classifiers are nine. Train set is used to train each classifier.

10. After training each classifier, test set is used to measure the performance of each classifier.

Table 1.Complete Accuracy Percentages from 9 Classifiers

\begin{tabular}{|c|c|c|}
\hline No. & Model & Accuracy (\%) \\
\hline 1 & Nearest Neighbors & $20.833 \%$ \\
\hline 2 & Linear SVM & $18.750 \%$ \\
\hline 3 & RBF SVM & $18.750 \%$ \\
\hline 4 & Gaussian Process & $14.583 \%$ \\
\hline $\mathbf{5}$ & Decision Tree & $\mathbf{3 1 . 2 5 0 \%}$ \\
\hline 6 & Random Forest & $16.667 \%$ \\
\hline 7 & Neural Net & $20.833 \%$ \\
\hline 8 & AdaBoost & $29.167 \%$ \\
\hline 9 & Naive Bayes & $29.167 \%$ \\
\hline
\end{tabular}

It can be seen from Table 1 that the highest accuracy percentage from 9 classifiers is Decision Tree, which is $31.250 \%$.

\section{Discussions and Conclusions}

Discussions

The relationship between country risk ratings with company performance

According to the above research result, it is can be explained that company performance which is measured by Return on Investment (ROI) is not directly affected by country risk ratings. It means that there is no significant differences in the ROI even though country risk ratings differ.

But when the company performance is being measured by Return on Equity (ROE), according to the above research result, it is can be explained that ROE is directly affected by country risk ratings. Based on the equation, we can see that the relationship is negative, meaning that increasing country risk premium will reduce the value of ROE. The result of this research not in line with Erb et al. (1996) research result, it is said that the higher country risk should be linked to higher expected return.

\section{Predicting country risk rating using machine learning algorithms}

The machine learning algorithms that we will use to predict country risk ratings are as follows: Nearest Neighbors, Linear Support Vector Machines, Radial Bases Functions Support Vector Machines, Gaussian Process, Decision Tree, Random Forest, Neural Net, Ada Boost, and Naive Bayes. According to the above research result, it can be seen from Table 1 (pages 13) that the highest accuracy percentage from 9 classifiers is Decision Tree, which is $31.250 \%$. We can conclude that the Decision Tree has the advantage of predicting the country risk rating more accurately than the other eight classifiers.

\section{Conclusions}


According to above research, it can be concluded that:

1. Based on ANOVA X1Y1 with F value $=4.278, \mathrm{p}>0.05$, indicates that there is no relationship between country risk premium with ROI; which means that ROI is not directly affected by country risk premium although the data comes from multinational companies.

2. Based on ANOVA X1Y2 with F value $=0.015, \mathrm{p}<0.05$, indicates that there is relationship between country risk premium with ROE; which means that ROE is affected by country risk premium. However, the relationship is negative, meaning that increasing country risk premium will reduce the value of ROE. Moreover, this effect is found to be very small based on the calculation of adjusted $\mathrm{R}$ square that is only by $2.3 \%$.

3. From all nine classifiers that been used in this research, the Decision Tree is the classifier that provides the highest accuracy rate for predicting country risk ratings based on the economic overview data provided by Euler Hermes. The results stated that Decision Tree classifier produces a level of accuracy $31.25 \%$ to predict country risk ratings.

\section{Research Limitations and Direction for Further Research}

\section{Research Limitations}

All the research sample are banking companies, which is multinational companies listed on the Southeast Asia Stock Exchange from 2010-2015. We are difficult to find any other form of companies besides of banking companies, because these companies are mostly renamed and not the same as the parent's company name; while banking companies use the same name as the parent.

Although there are other instruments which can be utilized as dependent variables such as increase of company share prices, and company values, we opt to choose ROI and ROE as proxies of company performance due to the scarcity of data. In addition, we utilize cross-sectional data in year 2015 to predict country risk ratings with machine learning algorithms on account of the country risk data limitation.

\section{Direction for Further Research}

For further research, the unit of analysis can be developed on several types of companies, not just the field of banking business only; hence the analysis results can be generalized to all companies. Furthermore, some other dependent variables besides ROI and ROE such as increase of company share prices and company values can be incorporated to compute company performance.

While the analysis is done by using machine learning algorithms, suggestions can also be given to use time series data for future directions. Specifically, the analysis accuracy of machine learning algorithms should be increased if the data set taken from Euler Hermes consists of several years.

\section{References}

Barber, D. 2012. Bayesian Reasoning and Machine Learning. Cambridge University Press.

Blei, D. M., Ng, A. Y., and Jordan, M. I. 2003. Latent Dirichlet Allocation. The Journal of Machine Learning Research 3: 993-1022.

Brigham, E. F., and Gapenski, L. C. 1993. Intermediate Financial Management 4th Edition. Fort worth Dryden Press.

COSO. 2004. Enterprise Risk Management - Integrated Framework. Executive Summary. www.coso.org.

Damodaran, A. 2016. Equity Risk Premiums (ERP): Determinants, Estimation and Implications - The 2016 Edition.

Damodaran, A. 2017. Country Default Spreads and Risk Premiums.

Erb, C. B., Harvey, C. R., and Viskanta, V. E. 1996. Expected Return and Volatily in 135 Countries. The Journal of Portfolio Management: 46-58.

Fan, W., Wallace, L., Rich, S., and Zhang, Z. 2006. Tapping the Power of Text Mining. Communications of the ACM.

Handayani, D., Korompot, N., and Hadjaat, M. 2011. Analisis Kinerja Keuangan Berdasarkan Rasio Profitabilitas Pada PT.Bhimex di Samarinda. Publikasi Ilmiah Vol 1, No 1.

Hearst, M. 2003. What Is Text Mining? Retrieved from Marti A. Hearst's Personal Website http:/ / people.ischool.berkeley.edu/ hearst/text-mining.html

Hotho, A., Nurnberger, A., and Paas, G. 2005. A Brief Survey of Text Mining. Ldv Forum: 19-62. 
Hoyt, R. E., and Liebenberg, A. P. 2011. The Value of Enterprise Risk Management: Evidence from the U.S. Insurance Industry. The Journal of Risk and Insurance: 795-822.

Husnan, S. 2001. Dasar-dasar Teori Portfolio dan Analisis Sekuritas. Edisi Ketiga. Unit Penerbit dan Percetakan Akademi Manajemen Perusahaan Yayasan Keluarga Pahlawan Negara, Yogyakarta.

Jogiyanto. 2007. Metodologi Penelitian Bisnis: Salah Kaprah dan Pengalaman-Pengalaman. Badan Penerbitan Fakultas Ekonomi - Universitas Gadjah Mada, Yogyakarta.

Kao, A., and Poteet, S. R. 2007. Natural Language Processing and Text Mining. Springer Science and Business Media.

Nafarin, M. 2007. Penganggaran Perusahaan. Salemba Empat, Jakarta.

Martono and Harjito, D. A. 2005. Manajemen Keuangan Perusahaan. Edisi Pertama Cetakan Kelima Ekonisia, Yogyakarta.

Michelle and Megawati. 2005. Tingkat Pengembalian Investasi Dapat Diprediksi Melalui Profitabilitas, Likuiditas dan Leverage. Kumpulan Jurnal Ekonomi.com.

Mihaela, E., and Alina, F. 2011. Country Risk Importance on Investment Decision Making. Romania. http://www.management.ase.ro.

Petrović, E., and Stanković, J. 2009. Contry Risk And Effects Of Foreign Direct Investment. Facta Universitatis Series: Economics and Organization Vol. 6, No 1: 9 - 22.

Sanjaya, C. K., and Linawati, N. 2015. Pengaruh Penerapan Enterprise Risk Management dan Variabel Kontrol Terhadap Nilai Perusahaan di Sektor Keuangan. FINESTA Vol. 3, No. 1: 52-57.

Sartono, R. A. 2008. Manajemen Keuangan. Edisi Keempat Badan Penerbitan Fakultas Ekonomi - Universitas Gadjah Mada, Yogyakarta.

Shenkir, W. G., and Walker, P. L. 2007. Enterprise Risk Management: Tools and Techniques for Effective Implementation. Institute of Management Accountants, New Jersey.

Staines, J. 2015. Mining Text and Time Series Data with Applications in Finance. PhD Thesis UCL (University College London), London.

Sugiyono. 2009. Metode Penelitian Kuantitatif dan Kualitatif. CV. Alfabeta, Bandung.

Sutrisno. 2009. Manajemen Keuangan Teori, Konsep, dan Aplikasi. Ekonisia, Yogyakarta.

The Economist Group Intellegence Unit. 2016. Country Risk Model - An Interactive Tool for Analysing Country and Sovereign Risk. www.eiu.com.

http://www.eulerhermes.com. 